\title{
Monitoring Status Gizi Balita Secara Online
}

\author{
(Monitoring of Toddler Nutrition Status Online) \\ Deniar Risma Putri ${ }^{1}$, Endah Sudarmilah ${ }^{2}$ \\ ${ }^{1,2}$ Program Studi Informatika, Universitas Muhammadiyah Surakarta, Indonesia \\ ${ }^{1}$ deniar.rp@gmail.com \\ ${ }^{2}$ Endah. Sudarmilah@ums.ac.id
}

\begin{abstract}
Abstrak - Tingkat kesejahteraan masyarakat di Indonesia saat ini masih belum merata sehingga berdampak pada tingkat kesehatan masyarakat. Salah satu penyebab utama terhambatnya pertumbuhan dan kematian anak-anak prasekolah di negara-negara berkembang adalah kurang gizi. Tujuan dari penelitian ini adalah merancang dan membangun sistem untuk menentukan nilai status gizi dan memantau perkembangan balita menggunakan metode $Z$ score. Metode $Z$-score adalah standar WHO 2005 dalam mengukur dan memantau pertumbuhan balita. Metode penelitian dilakukan dengan menggunakan metode System Development Life Cycle (SDLC) waterfall. Model pengembangan ini bersifat linear dari tahap awal pengembangan sistem sampai tahap akhir pengembangan sistem. Hasil dari penelitian ini adalah sebuah sistem yang dapat membantu petugas Posyandu dalam mengukur dan memantau status gizi balita.
\end{abstract}

Kata Kunci : Status Gizi Balita, Z-score, SDLC

\begin{abstract}
The level of welfare of the people in Indonesia is currently not evenly distributed so that it impacts on the level of public health. One of the main causes of stunted growth and death of preschool children in developing countries is malnutrition. The purpose of this study is to discuss and build a system to determine the value of nutritional status and improve the development of infants using the Z-score method. The Z-score method is $2005 \mathrm{WHO}$ standard for measuring and measuring toddler growth. The research method was carried out using the Waterfall Life Cycle Development System (SDLC) method. This Development Model is linear from the initial development system to the end of the development system. The results of this study are a system that can help Posyandu officers measure and monitor the nutritional status of children under five.
\end{abstract}

Keywords: Toddler Nutrition Status, Z-score, SDLC

\section{PENDAHULUAN}

Tingkat kesejahteraan masyarakat di Indonesia saat ini masih belum merata sehingga berdampak pada tingkat kesehatan masyarakat. Salah satu penyebab utama terhambatnya pertumbuhan dan kematian anakanak prasekolah di negara-negara berkembang adalah kurang gizi [1]. Jika permasalahan kekurangan gizi tidak terselesaikan maka dapat mengganggu pembangunan ekonomi Negara [2]. Kelompok usia yang sering terkena masalah gizi adalah balita [3]. Pada kelompok tersebut mengalami siklus pertumbuhan dan perkembangan yang membutuhkan zat-zat gizi yang lebih besar dari kelompok umur lainnya [4]. Akibat dari kekurangan gizi adalah pertumbuhan anak terganggu, produksi tenaga kurang, kurangnya daya tahan tubuh, terganggunya kecerdasan dan perilaku. Sedangkan akibat kelebihan gizi akan terjadi kegemukan yang dapat menyebabkan penyakit degeneratif [5]. Permasalahan gizi dapat ditentukan melalui pemerikasaan laboratorium dan Antropometri [6]. Antropometri adalah ilmu yang dibuat dari sub-disiplin ilmiah baru yang disebut antropologi fisik yang merupakan implikasi dari pengembangan studi antropologi [7] .

Berdasarkan Keputusan Menteri Kesehatan Republik Indonesia Nomor: 1995/MENKES/SK/XXI/2010 tentang standar antropometri penilaian status gizi anak, menimbang bahwa untuk menilai status gizi anak diperlukan standar antropometri yang mengacu pada WHO 2005 [8]. Parameter yang digunakan dalam penentuan status gizi balita yaitu umur, jenis kelamin, berat badan, tinggi badan, lingkar lengan atas dan lingkar kepala [9]. Kombinasi antara beberapa parameter disebut indeks antropometri. Pada umumnya indeks antropometri yang digunakan yaitu $(\mathrm{BB} / \mathrm{U}),(\mathrm{TB} / \mathrm{U})$ dan $(\mathrm{BB} / \mathrm{TB})[10]$. Untuk menilai status gizi, maka angka berat badan dan tinggi badan setiap balita dikonversikan ke dalam bentuk nilai standar (Z-Score) dengan menggunakan baku antropometri WHO 2005 [11].

Pemantauan tumbuh kembang balita sangat diperlukan untuk mengetahui adanya gangguan pertumbuhan sejak dini [12]. Biasanya pemantauan dilakukan oleh petugas Posyandu setiap bulannya dengan cara mengukur dan mencatat hasil perkembangan balita pada Kartu Menuju Sehat (KMS) secara manual, dimana hal tersebut rentan akan kesalahan dan kerancuan dalam menentukan nilai status gizi balita. Menghitung Z-score secara manual cukup rumit untuk dilakukan terutama ketika jumlah bayi yang diukur status gizinya relatif besar [13]. Maka dari itu 
penelitian dibuat yang bertujuan untuk merancang dan membangun mengenai sebuah sistem yang dapat membantu petugas Posyandu dalam mengukur dan memantau status gizi balita menggunakan standar WHO 2005 yaitu dengan menggunakan metode $Z$-score dengan judul "Monitoring Status Gizi Balita Secara Online".

\section{METODE}

Rancang bangun sebuah perangkat lunak dapat dilakukan dengan berbagai macam metode diantaranya waterfall yang merupakan bagian dari SDLC (System Development Life Cycle), prototype [14] dan agile [15], pada penelitian ini digunakan metode System Development Life Cycle (SDLC) waterfall. Model pengembangan ini bersifat linear dari tahap awal sampai tahap akhir pengembangan sistem [14]. Tahapan dari metode System Developmnet Life Cycle (SDLC) waterfall dapat dilihat pada Gambar 1.

\section{A. Analisis Kebutuhan}

1) Non-Fungsional. Kebutuhan non-fungsional untuk pembuatan sistem ini antara lain:

a) Hardware: Laptop ASUS (Processor Intel ${ }^{\circledR}$ Core ${ }^{\mathrm{TM}}$ 15-6200U CPU @ 2.30GHz 2.40GHz).

b) Software: PHP (Page Hyper Text Pre-Processor), CSS (Cascading Style Sheet), Javascript, DBMS MySQL, Sublime Text Editor, Visual Paradigm, DBDesigner 4, Balsamiq Mockups 3.

2) Fungsional. Kebutuhan fungsional untuk pembuatan sistem ini antara lain:

a) Petugas melakukan login.

b) Petugas memilih menu data balita.

c) Petugas memilih menu antropometri.

d) Petugas memilih menu status kategori ambang.

e) Petugas melakukan cek status gizi.

f) Petugas memasukkan data balita.

g) Petugas mengubah data balita.

h) Petugas menghapus data balita.

\section{B. Desain}

Perancangan sistem aplikasi menerangkan mengenai perancangan Use Case Diagram, perancangan Activity Diagram, perancangan ER-Diagram dan perancangan User Interface. Perancangan bertujuan untuk menentukan, mengorganisir, dan membentuk komponen dari solusi sistem akhir sehingga memiliki blueprint untuk membangun sistem.

1) Use Case Diagram. Use case sistem ini dapat digambarkan seperti Gambar 2 dapat diartikan bahwa pada sistem ini pengguna sekaligus adminnya adalah petugas Posyandu yang dapat melakukan kegiatan antara lain : login, memilih menu data balita, memilih menu antropometri, melakukan cek status gizi, memasukkan data balita, mengubah data balita dan menghapus data balita.

2) Activity Diagram. Activity Diagram sistem ini adalah dimulai dari petugas melakukan login kemudian database melakukan pencarian data dan sistem melakukan validasi username dan password, jika salah maka kembali kembali ke halaman login dan user memasukkan username dan password yang benar. Apabila sudah benar maka sistem menampilkan halam utama dan user dapat memilih menu sesuai dengan aktivitas yang akan dilakukan. Activity Diagram sistem ini dapat digambarkan seperti Gambar 3.

3) ER-Diagram. Tabel ER-Diagram sistem ini dapat digambarkan seperti Gambar 4 terdiri dari tujuh table antara lain : table antropometri yang menyimpan data antropometri, table balita menyimpan data balita, table orangtua menyimpan data orangtua balita, table posyandu menyimpan data posyandu, table monitoring menyimpan data yang dibutuhkan untuk monitoring status gizi, table admin menyimpan username dan password, dan table setting yang digunakan untuk menyimpan pengaturan.

4) User Interface. Tampilan awal pada sistem adalah halaman untuk login admin dengan memasukkan username dan password, kemudian jika admin berhasil login akan menuju halaman dashboard yang berisi pilihan menu yang ada di sistem. Untuk mengetahui balita yang terdaftar di Posyandu, admin dapat memilih menu data balita maka akan muncul halaman seperti Gambar 5. Jika admin ingin melakukan pengecekan status gizi dapat memilih menu cek status gizi maka akan muncul halaman berisi form untuk input berart badan,tinggi badan dan umur balita. Kemudian untuk melihat informasi nilai standar deviasi terdapat di halaman standar Antropometri seperti pada Gambar 6 dan informasi mengenai kategori status gizi balita di halaman kategori \& Z-score.

\section{Coding/Program}

Tahap ini dimulai dari pembuatan database sistem kemudian dilanjutkan dengan membuat tampilan dan coding PHP serta query MYSQL. Pembuatan tampilan menggunakan framework bootstrap dan framework CodeIgniter untuk coding PHP serta query MySQL.

\section{Testing}

Tahap ini digunakan untuk menguji fitur-fitur yang terdapat pada sistem apakah fitur-fitur tersebut sudah berjalan sesuai dengan semestinya atau belum. Pengujian dilakukan dengan menggunakan black box testing dan System Usability Scale (SUS). 


\section{E. Implementasi}

Implementasi dapat diartikan sebagai proses untuk memastikan terlaksananya dan tercapainya kebijakan tersebut. Tahap ini merupakan tahap yang terakhir dan dapat dilakukan ketika sistem telah selesai dibangun.

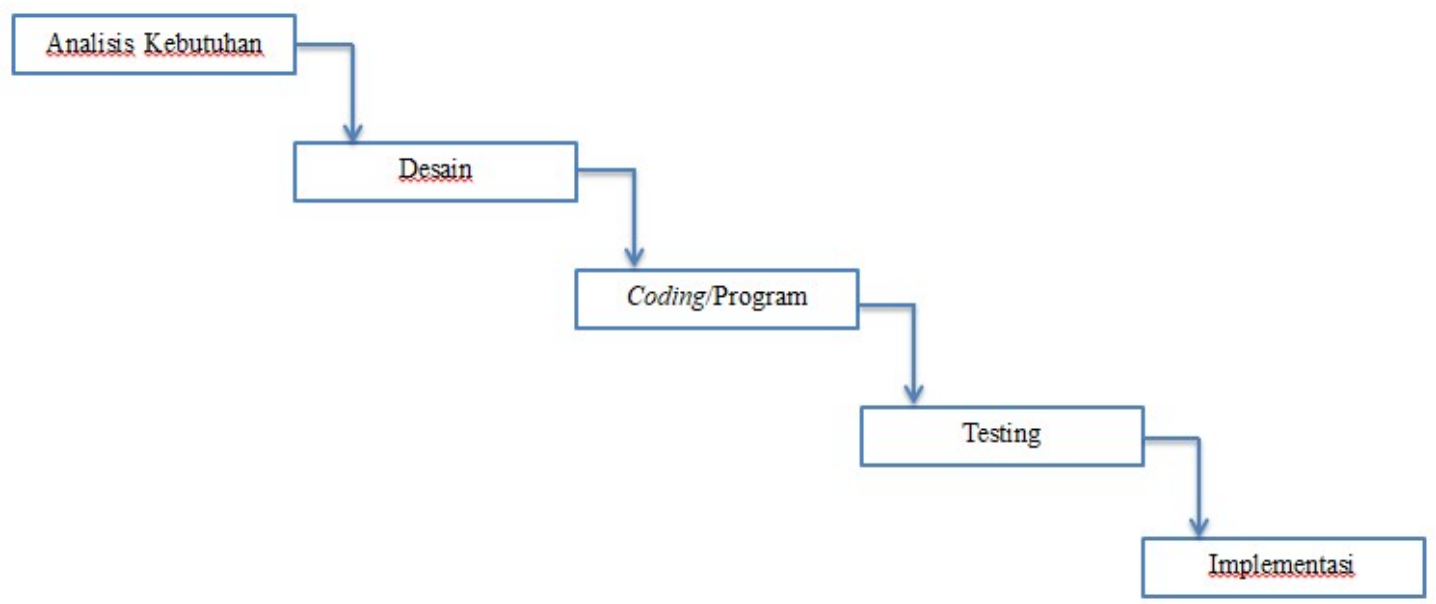

Gambar 1. System Developmnet Life Cycle (SDLC) waterfall

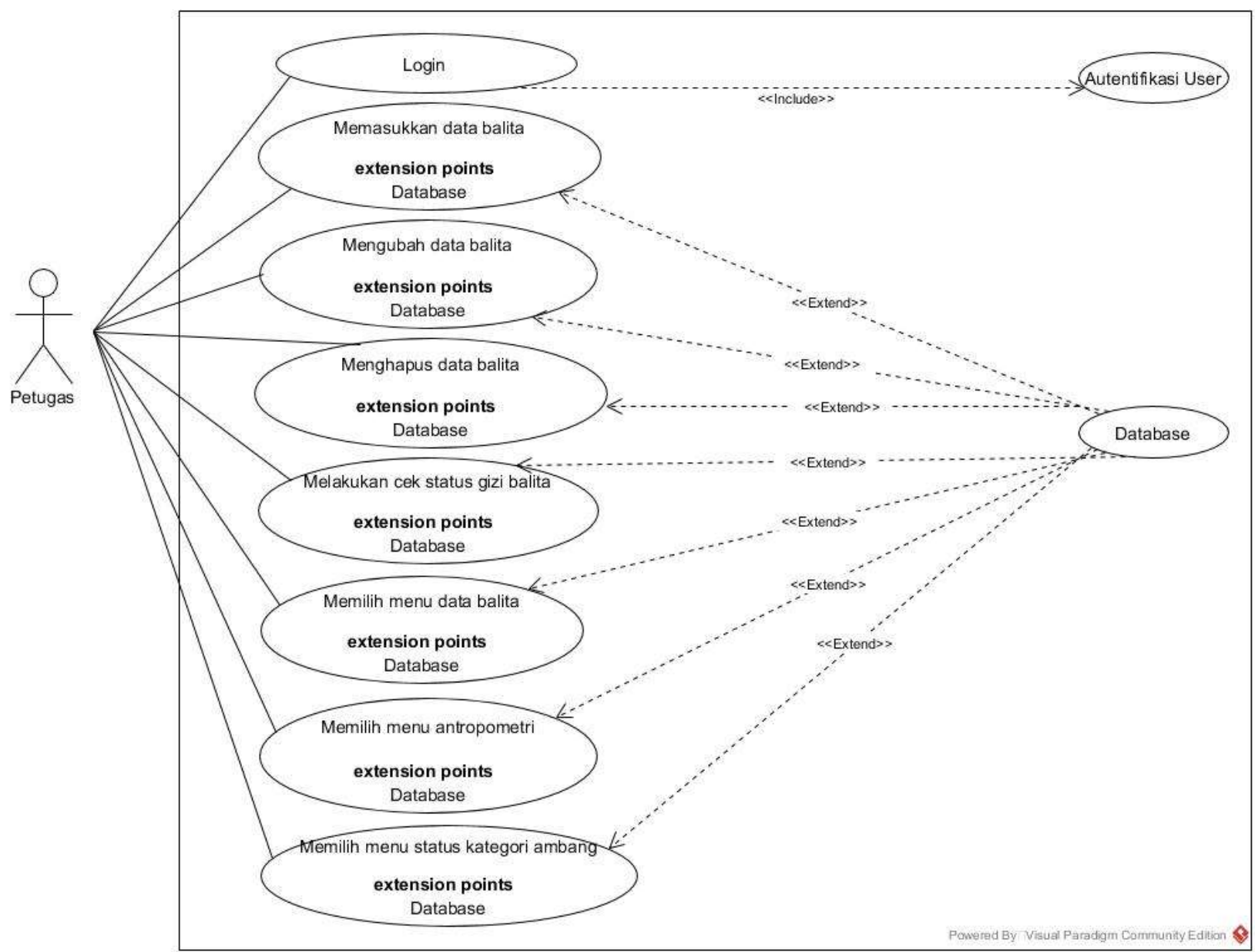

Gambar 2. Use Case Diagram 


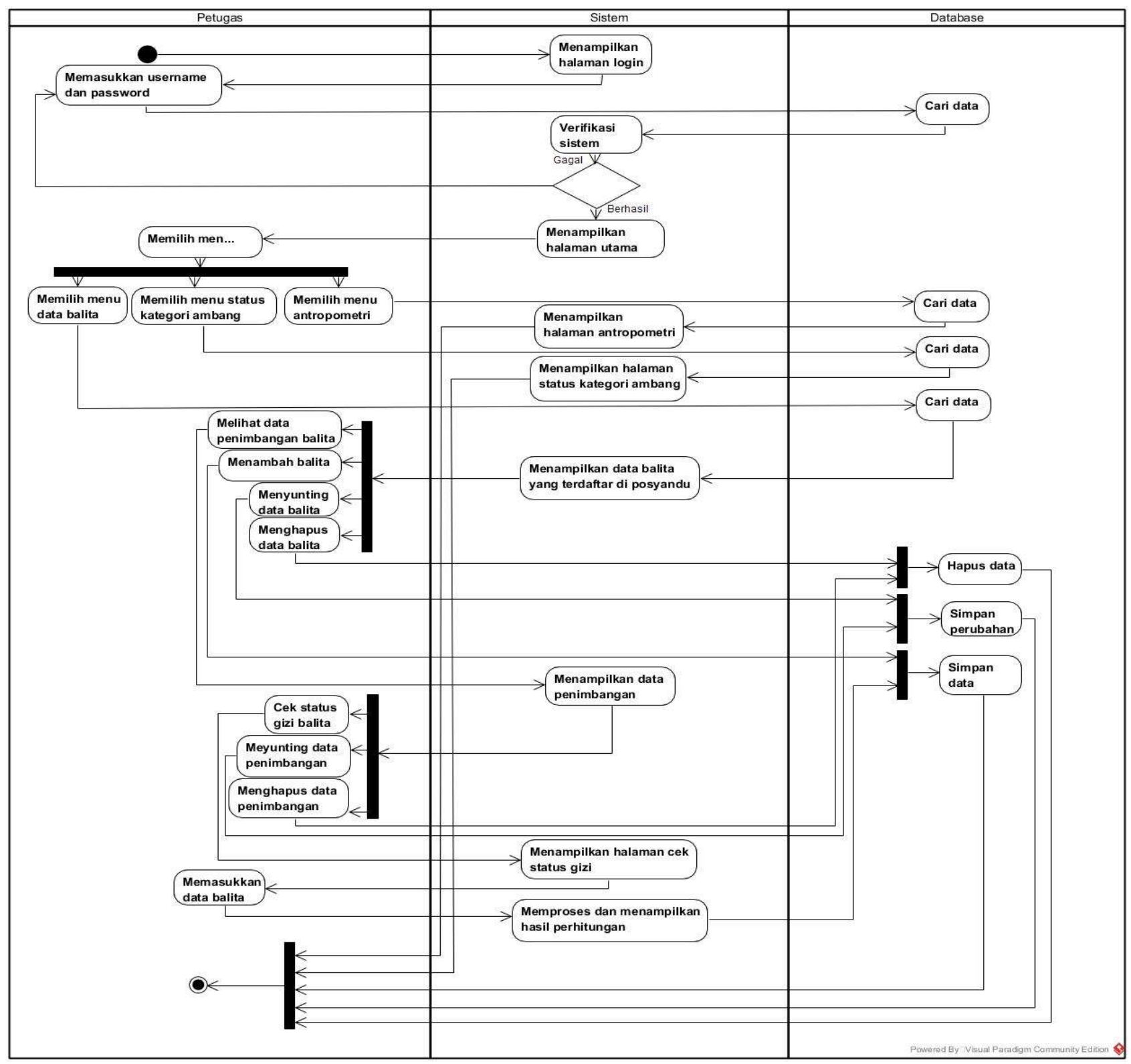

Gambar 3. Activity Diagram 


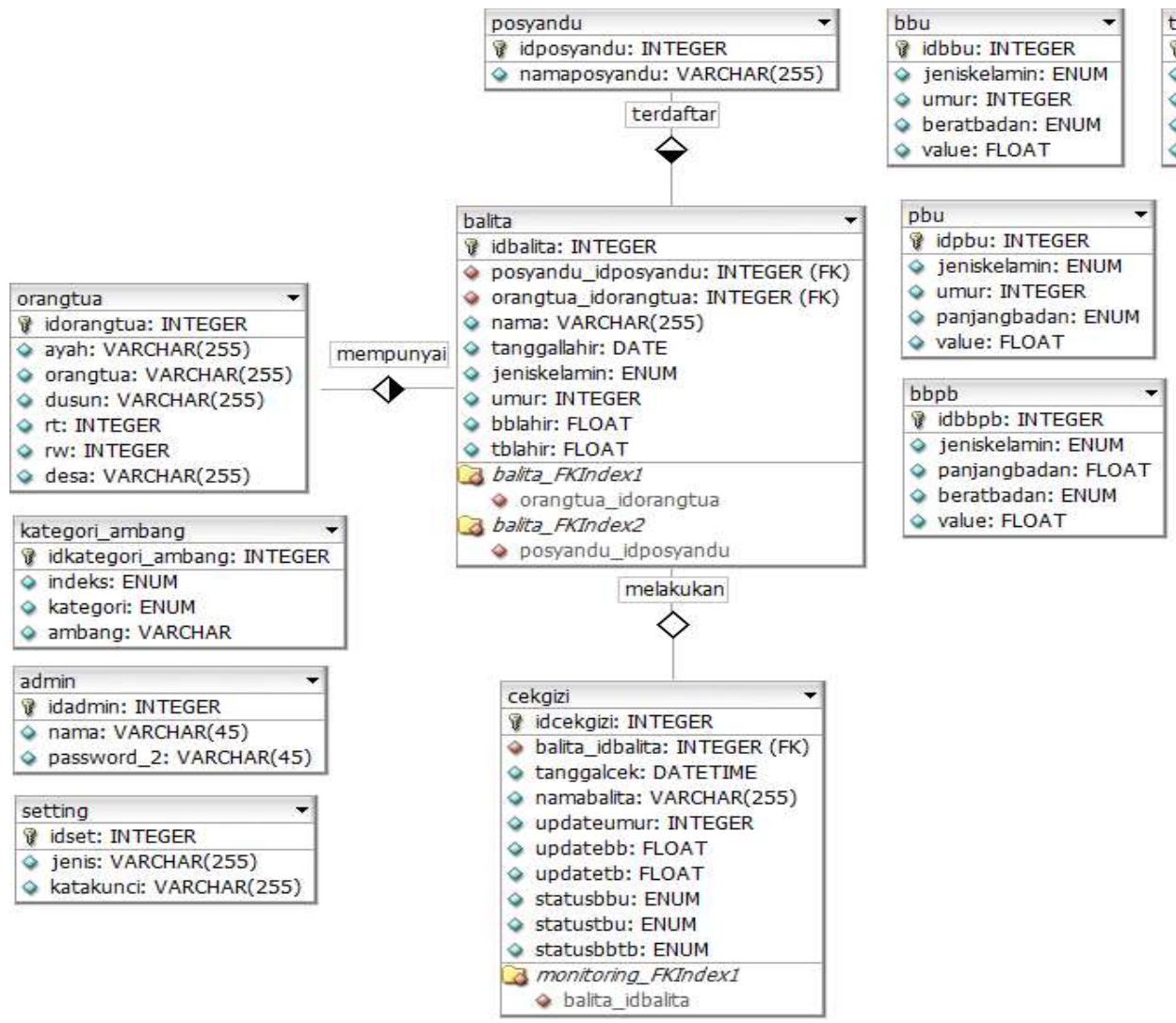

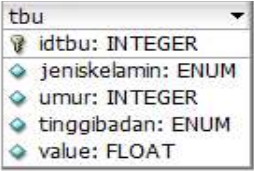

bbtb

idbbtb: INTEGER

$\checkmark$ jeniskelamin: ENUM

$\checkmark$ tinggibadan: FLOAT

$\checkmark$ beratbadan: ENUM

$\diamond$ value: FLOAT

Gambar 4. ER-Diagram

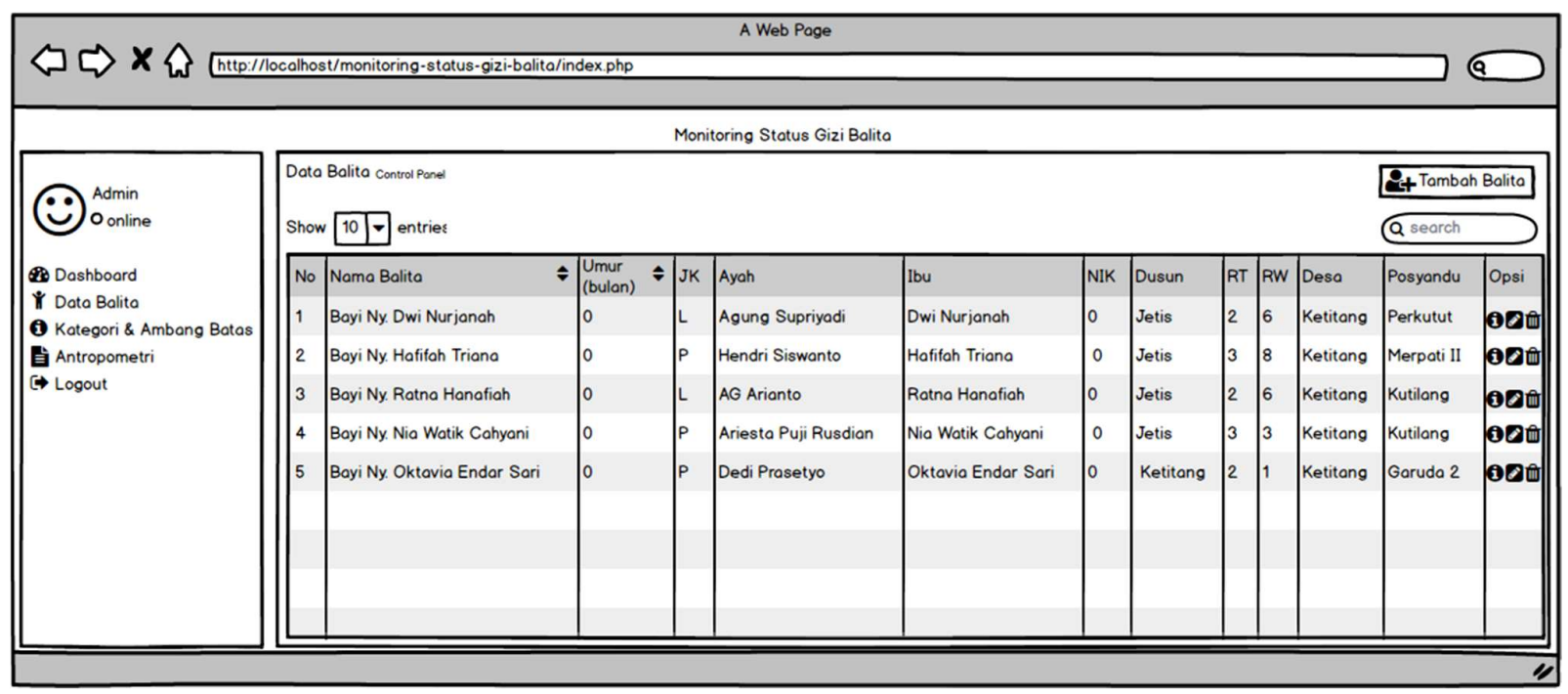

Gambar 5. Halaman Data Balita 


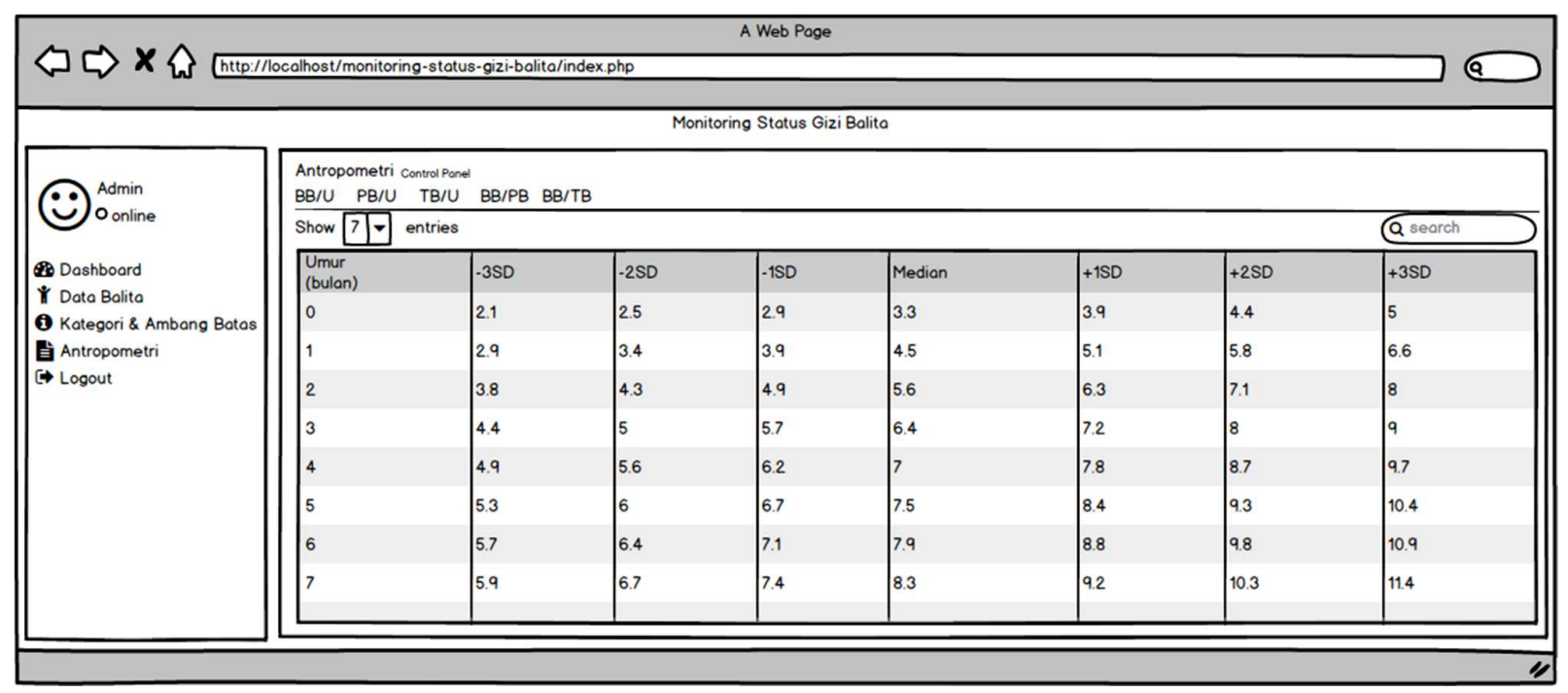

Gambar 6. Halaman Standar Antropometri

\section{HASIL DAN PEMBAHASAN}

\section{A. Hasil}

Hasil dari penelitian ini adalah sebuah sistem yang dapat membantu petugas Posyandu dalam mengukur dan memantau status gizi balita. Sistem yang telah selesai dibangun dan sudah diimplementasikan ini hanya dapat diakses oleh admin, yaitu petugas Posyandu itu sendiri. Berikut merupakan hasil dari penelitian.

1) Halaman login merupakan halaman yang akan tampil pertama kali ketika sistem dibuka. Pengguna harus memasukkan username dan password untuk dapat mengakses sistem.

2) Halaman dashboard merupakan halaman yang akan tampil pertama kali ketika pengguna berhasil login ke sistem yang berisi pilihan menu yang ada pada sistem.

3) Halaman data balita menyajikan daftar nama balita yang terdapat di Posyandu dan informasi mengenai balita tersebut. Halaman data balita dapat dilihat pada Gambar 7.

4) Halaman tambah balita menyajikan form yang digunakan untuk input data balita yang akan didaftarkan di Posyandu dengan mengisi beberapa informasi yang dibutuhkan seperti data balita, data orangtua dan alamat.

5) Halaman data penimbangan balita memberikan informasi mengenai data penimbangan yang dilakukan setiap bulannya yang disajikan dalam bentuk tabel dan grafik seperti yang dapat dilihat pada Gambar 8 .

6) Halaman cek status gizi digunakan untuk input hasil penimbangan berat badan dan pengukuran tinggi badan balita setiap bulannya serta untuk mengetahui status gizi balita.
7) Halaman kategori \& Z-score menampilkan informasi mengenai kategori status gizi balita berdasarkan nilai standar deviasi Z-score seperti pada Gambar 9.

8) Halaman standar antropometri menampilkan informasi nilai standar deviasi setiap Antropometri yang digunakan untuk penilaian status gizi balita seperti yang dapat dilihat pada Gambar 10.

\section{B. Pengujian dan Pembahasan}

1) Pengujian Black-Box. Pengujian Black-Box dilakukan untuk menguji apakah fitur sudah berjalan sesuai dengan semestinya atau belum. Pengujian BlackBox meliputi kelas uji, sekenario uji, hasil yang diharapkan dan hasil uji seperti yang dapat dilihat pada TABEL 1.

2) Pengujian System Usability Scale (SUS). Tahapan ini dilakukan untuk evaluasi terhadap sistem menggunakan pengujian System Usabilty Scale (SUS) untuk mengetahui seberapa baik sistem diimplementasikan. System Usabilty Scale (SUS) berupa kuesioner untuk mengukur kegunaan sistem komputer sesuai dengan sudut pandang subyektif pengguna. Kuesioner SUS menggunakan 5 poin skala Likert. Responden diminta untuk memberikan penilaian sistem mulai dari "Sangat tidak setuju", "Tidak setuju", "Netral", "Setuju", dan "Sangat setuju" pada 10 item pernyataan. Setiap item pernyataan memiliki variabel R1 hingga R10 [16]. Skor SUS keseluruhan diperoleh dari rata-rata skor SUS individu dengan menggunakan rumus Persamaan 1.

$$
\begin{aligned}
& \text { SUS }=(((R 1-1)+(5-R 2)+(R 3-1)+ \\
& (5-R 4)+(R 5-1)+(5-R 6)+(R 7-1)+ \\
& (5-R 8)+(R 9-1)+(5-R 10)) * 2.5) \ldots(1)[17]
\end{aligned}
$$


Pada TABEL 2 menunjukan hasil uji usability data kuesioner dengan menggunakan perhitungan rumus SUS dengan kriteria pernyataan:

a) Menurut saya, saya akan sering menggunakan sistem ini

b) Menurut saya sistem ini terlalu rumit digunakan

c) Menurut saya sistem ini mudah digunakan

d) Saya membutuhkan bantuan orang lain untuk menggunakan sistem ini

e) Saya menganggap fitur-fitur pada sistem ini dapat berjalan dengan baik

f) Menurut saya sistem ini membingungkan

g) Menurut saya orang lain akan cepat memahami menggunakan sistem ini

h) Saya menganggap sistem ini tidak praktis (sulit) digunakan

i) Saya merasa bisa menggunakan sistem ini j) Saya perlu belajar banyak untuk dapat menggunakan sistem ini

3) Hasil Perhitungan Menggunakan Formula SUS. Pada TABEL 2 diperoleh jumlah skor SUS kemudian dilakukan perhitungan nilai rata-rata. Rumus untuk menghitung nilai rata-rata dapat menggunakan Persamaan 2, sebagai berikut:

$$
\text { Rata }- \text { rata }=\frac{\sum x}{N}
$$

Keterangan:

$\mathrm{x}$ : Nilai Hasil Akhir Responden; N: Jumlah Responden

Sehingga, perhitungan nilai rata-rata menggunakan Persamaan 2 menghasilkan nilai 70,58. Nilai ini berada dalam rentang C (70-80), yang dapat dilihat pada Gambar 11 yaitu menunjukkan hasil "baik".

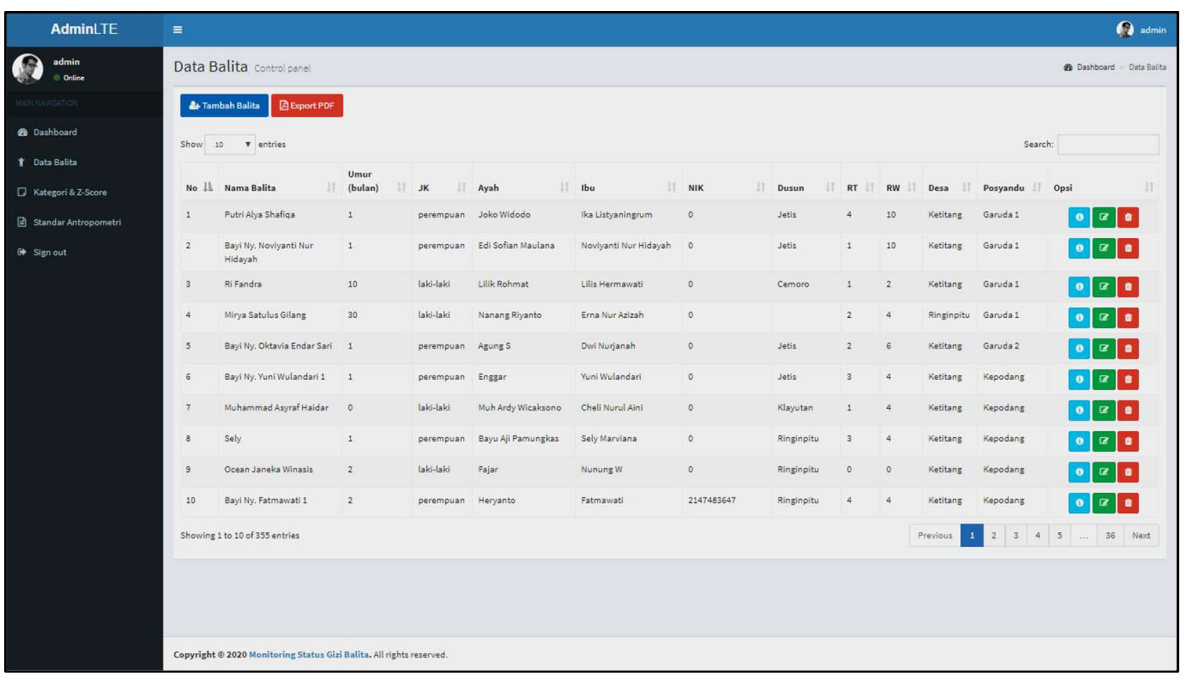

Gambar 7. Halaman data balita

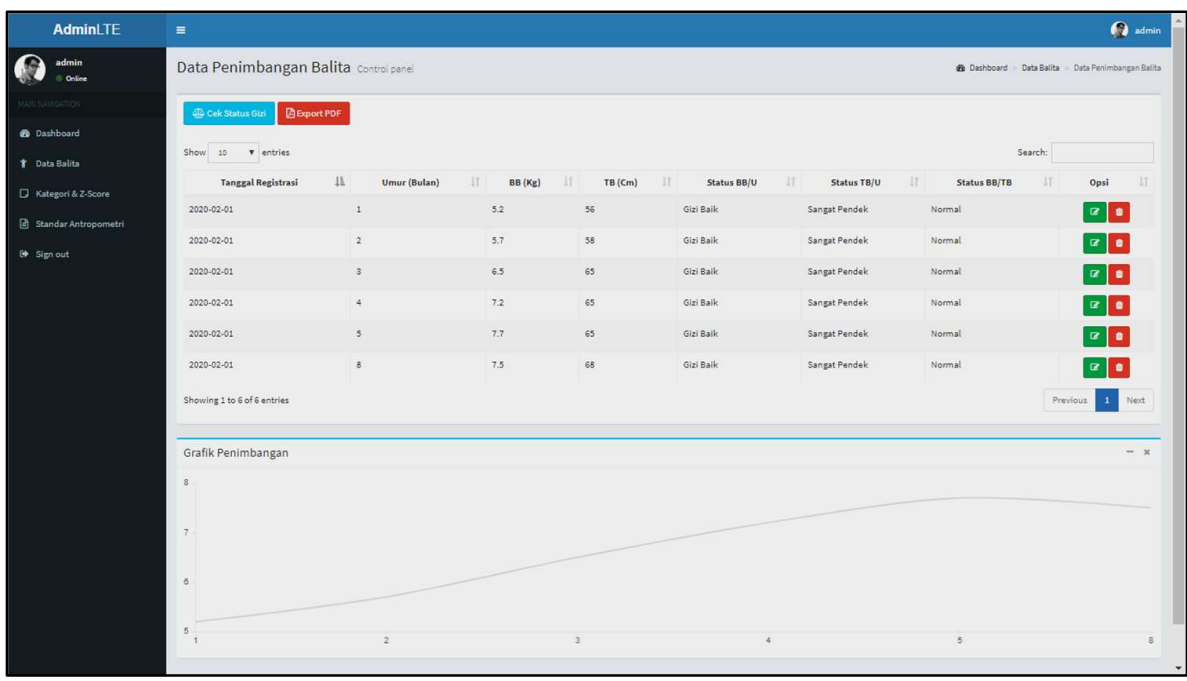

Gambar 8. Halaman data penimbangan balita 


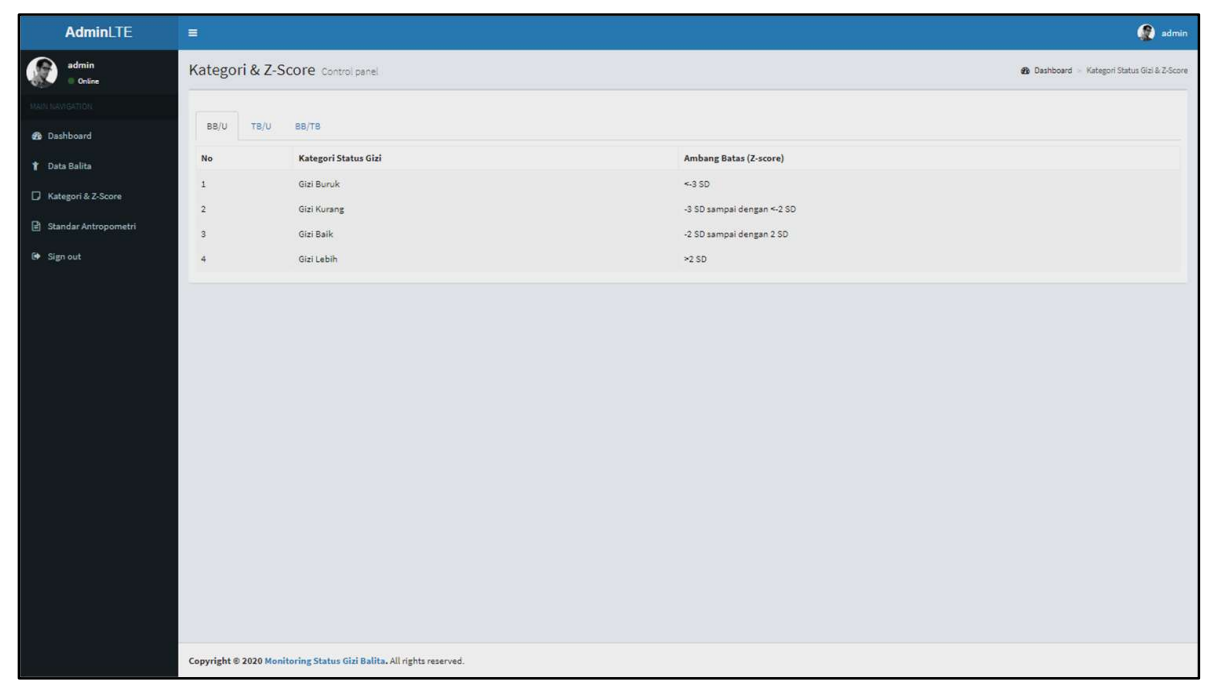

Gambar 9. Halaman kategori \& $Z$-score

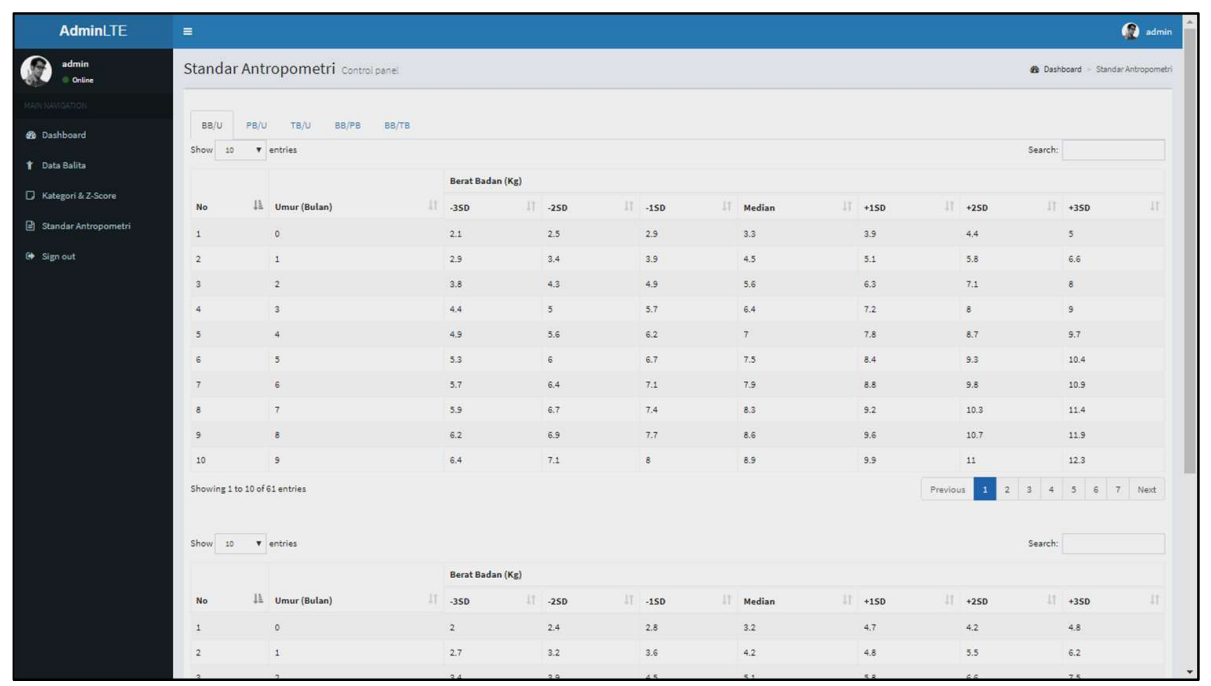

Gambar 10. Halaman standar antropometri

TABEL I

PENGUJIAN BLACK-BOX

\begin{tabular}{|c|c|c|c|}
\hline Kelas Uji & Skenario Uji & Hasil yang Diharapkan & Hasil Uji \\
\hline \multirow[t]{2}{*}{ Login } & $\begin{array}{l}\text { 1. Memasukkan username dan } \\
\text { password benar }\end{array}$ & $\begin{array}{l}\text { 1. Sistem menampilkan halaman } \\
\text { dashboard }\end{array}$ & \\
\hline & $\begin{array}{l}\text { 2. Memasukkan username dan } \\
\text { password salah }\end{array}$ & $\begin{array}{l}\text { 2. Sistem menampilkan halaman } \\
\text { login }\end{array}$ & Valid \\
\hline \multirow{4}{*}{$\begin{array}{l}\text { Logout } \\
\text { Data Balita }\end{array}$} & Menekan tombol logout & Menampilkan halaman login & Valid \\
\hline & Menekan menu data balita & Menampilkan halaman data balita & Valid \\
\hline & $\begin{array}{l}\text { Petugas menambah, } \\
\text { menampilkan info } \\
\text { penimbangan, mengubah dan } \\
\text { menghapus data balita }\end{array}$ & $\begin{array}{l}\text { Data balita dapat ditambah, } \\
\text { ditampilkan, diubah, dan dihapus }\end{array}$ & Valid \\
\hline & Menekan tombol Export PDF & $\begin{array}{l}\text { Menampilkan data balita dalam } \\
\text { format PDF dan dapat diunduh } \\
\text { atau dicetak }\end{array}$ & Valid \\
\hline
\end{tabular}


TABEL I (LANJUTAN)

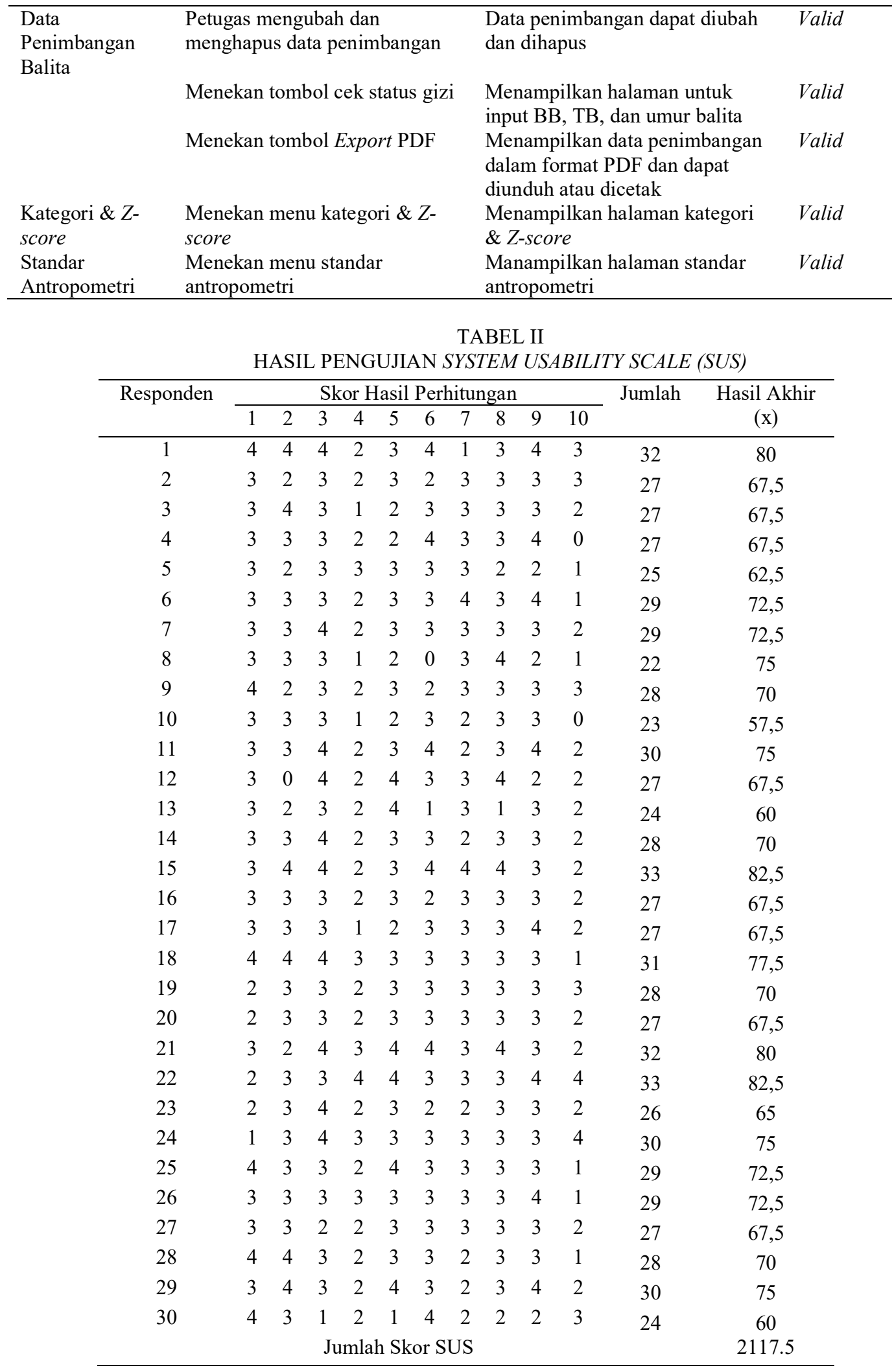




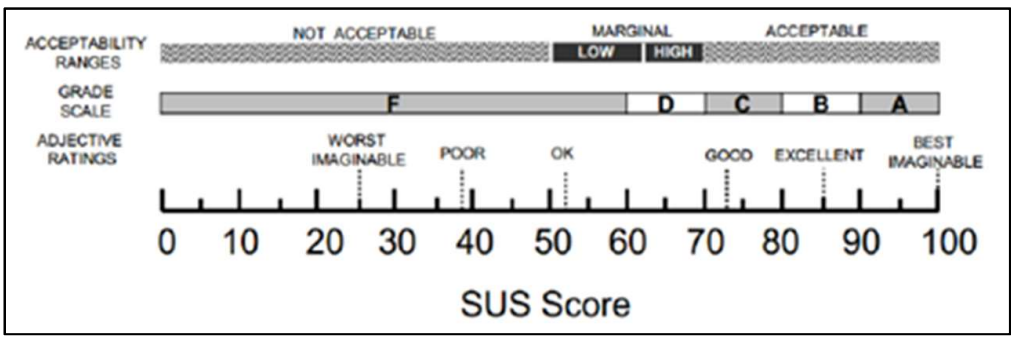

Gambar 11. Rentang Penilaian SUS [18]

\section{PENUTUP}

Sistem Monitoring Status Gizi Balita dapat membantu petugas dalam menentukan nilai status gizi dan memantau perkembangan balita. Berdasarkan blackbox testing yang sudah dilakukan sistem ini dapat berjalan dengan baik setiap fiturnya dan berdasarkan usability testing menggunakan SUS sistem ini diperoleh nilai rata-rata 70.58 yang artinya sistem ini masuk kedalam kriteria "baik".

\section{DAFTAR PUSTAKA}

[1] S. P. Giri, S. Biswas, and K. Bose, "Head circumference based nutritional status of rural Bengalee preschool children from Sagar Island, West Bengal, India," Mankind Q., vol. 58, no. 4, pp. 599-610, 2018.

[2] S. Winiarti, H. Yuliansyah, and A. A. Purnama, "Identification of Toddlers' Nutritional Status Using Data Mining Approach," Int. J. Adv. Comput. Sci. Appl., vol. 9, no. 1, pp. 164-169, 2018.

[3] P. D. Kartini, "Klasifikasi Status Gizi Balita Berdasarkan Indeks Anthropometri BB/U Menggunakan Metode KNN (K- Nearest Neighbor)," Simki-Techsain, vol. 01, p. 6, 2017.

[4] M. Dianingrum and A. Suryanto, "Penentuan Status Gizi Balita Berbasis Android Menggunakan Metode Analitycal Hierarchy Process (AHP)," JUITA (Jurnal Inform., vol. III, no. 1, pp. 11-17, 2014.

[5] H. M. Par'i, S. Wiyono, and T. P. Harjatmo, Penilaian Status Gizi, Tahun 2017. Jakarta Selatan: Pusat Pendidikan Sumber Daya Manusia Kesehatan, 2017.

[6] A. S. Putra, "Klasifikasi Status Gizi Balita Menggunakan Naive Byes Classification (Studi Kasus Posyandu Ngudi Luhur)," Universitas Sanata Dharma Yogyakarta, 2018.

[7] M. Badrul, R. Rusdiansyah, and C. Budihartanti, "Application of Simple Additive Weighting Method for Determination of Toddler Nutrition Status," SinkrOn, vol. 4, no. 1, p. 19, 2019.

[8] Kementrian Kesehatan, Standar Antropometri Penilaian
Status Gizi Anak. Jakarta: Kementrian Kesehatan, 2010.

[9] Y. D. Iriani, "Sistem Pendukung Keputusan Status Gizi Balita Menggunakan K-Nearest Neighbor," Universitas Jember, 2015.

[10] M. O. Fitri, “Aplikasi Monitoring Perkembangan Status Gizi Anak dan Balita Secara Digital dengan Metode Antropometri Berbasis Android," J. Inf. Sains dan Teknol., vol. 2, no. April, pp. 140-149, 2017.

[11] M. H. Wahyudi, "Sistem Pendukung Keputusan Penentuan Status Gizi Balita Menggunakan Metode Naive Bayes," in Seminar Nasional Teknologi Informasi dan Multi Media, 2018, pp. 25-30.

[12] I. K. Rahmawati, H. Hasanah, and J. Maulindar, "Aplikasi Monitoring Status Gizi Tubuh Balita dengan Metode Z Score Berbasis Android," in Seminar Nasional Teknologi Informasi dan Bisnis (SENATIB), 2017, pp. 147-154.

[13] A. Widodo, Mutalazimah, and B. Handaga, "Effectivity of Child Nutritional Status Monitoring Based on Information Technologyat District Health Office, Sukoharjo Regency," in ASEAN/Asian Academic Society International Conference Proceeding Series, 2015, pp. 121-125.

[14] R. Susanto and A. D. Andriana, "Perbandingan Model Waterfall Dan Prototyping," Majalah Ilmiah UNIKOM, vol. 14, no. 1, pp. 41-46, 2016.

[15] M. A. Rafeek, A. F. Arbain, and E. Sudarmilah, "Risk mitigation techniques in agile development processes," Int. J. Supply Chain Manag., vol. 8, no. 2, pp. 11231129, 2019.

[16] E. Febriyanto, U. Rahardja, A. Faturahman, and N. Lutfiani, "Sistem Verifikasi Sertifikat Menggunakan Qrcode pada Central Event Information," Techno.Com, vol. 18, no. 1, pp. 50-63, 2019.

[17] D. A. Mawsally and E. Sudarmilah, "A Virtual-Reality Edu-Game : Saving The Environment from the Dangers of Pollution," Khazanah Inform. J. Ilmu Komput. dan Inform., vol. 5, no. 2, pp. 140-145, 2019.

[18] D. Pratama, "Sistem Informasi Manajemen Berbasis Website," Universitas Muhammadiyah Surakarta, 2019. 